\title{
A new approach to the problem of the Neolithisation of the North-Pontic area: is there a north-eastern kind of Mediterranean Impresso pottery?
}

\author{
Dmytro Gaskevych \\ Institute of Archaeology, Kyiv, UA \\ gaskevych@ukrpost.ua
}

\begin{abstract}
Potsherds from a few vessels with Cardium decoration were recently found in old collections of some Neolithic sites of the Northern Black Sea area. A good samples of the valves of brackish water ostracods were discovered in the raw material in most of these vessels. This could indirectly indicate the presence of Neolithic settlements with Cardium pottery on what is now a flooded region of the northern Black Sea coast. Some data show that its inhabitants could have been the initial source of the Neolithisation of neighbouring inland territories. Thus, the whole local Neolithic in the region is interpreted as a northeastern branch of the Mediterranean Neolithic with Impresso and Cardium pottery.
\end{abstract}

IZVLEČEK - V starejših zbirkah nekaterih neolitskih najdišč s področja na severu Črnega morja so bili nedavno odkriti odlomki keramičnih posod s Cardium okrasom. Vlončarskih masah večine posod so bili odkriti tudi ostanki oklepov morskih rakov dvoklopnikov (Ostracoda) iz brakičnih okolij. To lahko posredno kaže na prisotnost neolitskih naselbin $s$ Cardium lončenino na področju obale na severu Črnega morja, ki je danes poplavljeno. Nekateri podatki kažejo, da bi lahko prebivalci tega področja predstavljali prvotni vir neolitizacije sosednjih območij v notranjosti. Tako lahko celoten lokalni neolitik $v$ teh regiji razlagamo kot severovzhodno vejo sredozemskega neolitika z impresso in Cardium lončenino.

KEY WORDS - Neolithic; Northern Black Sea area; Mediterranean; Cardium Impresso pottery; maritime colonization

\section{Introduction}

The Northern Black Sea area is a historical-geographical region limited in the south by the Black Sea, in the west by the lower reaches of the Danube and Prut rivers, and in the east by the lower reaches of the Kuban and the Don rivers. The northern border of the region is indistinct. Researchers usually include in this region the steppe zone and southern part of the forest-steppe zone extending approximately $200-250 \mathrm{~km}$ to the north from the coast of the Black Sea and Azov Sea, plus the territory of the Crimean Peninsula. The greater part of the Northern Black Sea area is in Ukraine; a small area is in the extreme west of the region, bordering Moldova, and to the east, the Rostov area and the Krasnodar re- gion of the Russian Federation. The landscape is mainly low-lying, with uplands in the west (the central-Moldavian upland), north (southern slopes of the Podolian and Dnipro (Dnieper) uplands), east (the Asov upland and Donetsk Range), and with the low Crimean Mountains in the south of the Crimean Peninsula. The absolute heights of the continental part of the region range from 0 up to $500 \mathrm{~m}$ above sea level, and the heights of the Crimean Mountains up to $1545 \mathrm{~m}$.

Only two archaeological cultures with a reliably complete 'Neolithic package' are known in the Northern Black Sea area. Firstly, the settlements of the Criş 
culture, investigated at the extreme west of the region at the interfluve of the Prut and Dnister (Dniester) River. Secondly, the settlements of Linear Band Pottery culture in an area between the Prut and the South Buh (Bug) River (Larina 1994a; 1994b; 1999). The most easterly Linear Band Pottery site is VitaPoshtova 2 (Gaskevych 2006). It is situated north of the Northern Black Sea area, close to Kyiv, only 10 kilometres from the valley of the Dnipro River. The population of both the Criş culture and Linear Band Pottery culture were classic early farmers from the Carpathians-Danube region. Consequently, the northwest part of the Black Sea area is the easternmost area of these cultures.

In Nadezhda Kotova's opinion, the full 'Neolithic package' is also present in the finds from the Rakushechny Yar site in the Lower Don area in the extreme east part of the region. She relates the origin of the people who left the materials to the migration of small groups of early farmers from Eastern Anatolia to the Azov Sea area $c .6900$ calBC (Kotova 2009. $164,165)$. But it should be noted that some components of the 'Neolithic package' mentioned by Kotova occur only in strata with radiocarbon dates from the $6^{\text {th }}$ millennium calBC at the Rakushechny Yar site. Consequently, their association with a hypothetical migration $c .6900$ calBC is not indispensable. Furthermore, there is no archaeological evidence of such migration through the Zagros and Caucasus Mountains, a distance of some $1500 \mathrm{~km}$. Therefore, the only real basis for the Nadezhda Kotova hypothesis is the presence of pottery and domestic animal bones in the lowest layers of the Rakushechny Yar site, and the close radiocarbon dates from the lowest layers of the Yumuktepe site and Rakushechny Yar site.

The Neolithic way of life spread very slowly in the Northern Black Sea area from outside territory, populated by migrants. The components of the 'Neolithic package' are partially present at local sites. Some archaeologists think that the beginnings of the spread of these innovations is related to the western influence of population of the Balkan and Danubian Neolithic cultures (e.g., Zaliznyak 1998a.230-237; 1998b; 2005.120-126; Zvelebil, Lillie 2000), while some relate this to the eastern influence of the population of the Rakushechny Yar culture (e.g., Kotova 2002.74-81; 2009).

Apart from actual hypotheses about the Neolithisation of the Northern Black Sea area, there were earlier hypotheses. Thus, for example, in the 1950s- 70s, Ukrainian archaeologist Valentin Danilenko related the genesis of the southern Ukrainian Neolithic to migrations from the territory in the Trans-Caspian region (Danilenko 1969.177-180). Yet a further hypothesis came from the Romanian archaeologist Dumitru Berciu, who casually, with no supporting argument, supposed the presence of the locus of Early Neolithic sites with Cardium pottery in the Northern Black Sea area:

"In the northern Pontic area, the same 'cardial' horizon can also be assumed, given the similarities between the culture of the Southern Bug River and that of Hamangia. Such a hypothesis can be supported by the identification of a horizon 'cardial' in Mesopotamia and Iran, where a cultural influx could have migrated to the Caucasus and south-eastern shores of the Black Sea." (Berciu 1966.292).

Berciu's hypothesis was forgotten during the following forty years, but in the last few years has become current again, after the ascertainment of new facts as presented in this article.

\section{The new data}

What undisclosed facts allowed Berciu to suggest his idea? For many years, in the context of Neolithic of the South Buh region, pottery with Cardium decoration had been mentioned only once by Valentin Danilenko in his 1969 monograph. It is a description of a single potsherd found on the Savran' site, close to the town of Savran' in the Odessa area in 1955. No figure of it has been published. The researcher only briefly wrote about this item as follows:

"... a piece of vessel rim, more than $1 \mathrm{~cm}$ thick, made from black clay and decorated with a herringbone row consisting of small angular impresses printed by bracket stamp. Some analogies are known only among fragments from pottery with the so-called Cardium decoration from the Adriatic region" (Danilenko 1969.132).

The author of the current article succeeded in finding this potsherd among the material in the collection of the Institute of Archaeology of the National Academy of Sciences of Ukraine. It is a fragment with a straight vertical rim $1.4 \mathrm{~cm}$ thick. The edge of the rim is rounded at first, and thence slightly flattened. The external surface is black sub-burnished; the internal surface is dark-brown, well smoothed. Two horizontal rows of alternately directed diagonal im- 
prints from the sinuous edge of a Cardium edule valve run along the rim on the outside (Fig. 1.1). Thus, this potsherd was decorated with real Cardium shell impressions, but not 'small angular impresses printed by bracket stamp', as described by Valentin Danilenko.

The vessel from which this fragment came was manufactured from raw material peculiar to local Neolithic pottery. It contains a small quantity of vegetal temper, sand, and a large quantity of valves of small (less than 1mm) seed shrimps (Ostracoda) of Cyprideis torosa littoralis (Brady, 1864), which gives the fragment a porous appearance. All identifications of ostracods and mollusc species mentioned in the article were by Valentin Prisyazhnyuk at the Institute of Geology of the National Academy of Sciences of Ukraine.

Unfortunately, the position of the rim fragment on the site makes it impossible to date accurately. Several concentrations of artefacts of the Eneolithic Trypillia, Neolithic Bug-Dniester, and Mesolithic Kukrek cultures were localised at the Savran' site (Danilenko 1969.125-134). The potsherd with Cardium decoration was found separately on the periphery. An Eneolithic flint triangular bifacially retouched javelin head, a Neolithic sherd representative of Savran' type pottery of the Bug-Dniester culture, a Mesolithic flint tool of so-called 'Kukrek insert' type, plus some ten ordinary flint artefacts, a few animal bones, and Unio freshwater mollusc shells were also found here. They were collected around a large granite block on the surface of a high area of the South Buh River flood-plain, broken by sand shallow delf, and also from a 24sq. m trench (Danilenko 1969.132). Based on the character of the finds and their occurrence on the surface and in a layer of sandy loam to a depth of $0.3 \mathrm{~m}$, I conclude that this excavation revealed some mix of redeposited scattered artefacts of different ages. Thus, the potsherd with Cardium decoration may be dated within a wide time frame from the $7^{\text {th }}$ to the $5^{\text {th }}$ millennium calBC (Gaskevych 2010.238).

Ukrainian archaeologist Mykola Tovkaylo focused on the hypothesis about the North Pontic Impresso Neolithic after my presentations and publications. As a result of his research, important new arguments were obtained in materials from the Neolithic sites in the steppe area of the South Buh basin, which he has been investigating for over twenty years. According to information he kindly provided, he recently found sherds from no fewer than five vessels with Cardium decoration in the collections of some sites he excavated earlier. A drawing of at least one from the pots has already been published by Tovkaylo, but he did not identify it as a fragment of Cardium pottery at the time (Tovkaylo 2005.130, Fig. 48.3). This vessel is represented by only one fragment of its rim, the edge of which is rounded; its surfaces and section are black. The external thickened edge of the rim is decorated by three rows of diagonal, four-fluted imprints of a notched stamp. Below it is a row of imprints of the ribbed back of a Cardium cockleshell (Fig. 1.2). The four-fluted imprints were most probably impressed with the same shell, but with its sinuous edge. The vessel is made of a raw material identical to the foregoing potsherd from the Savran' site.

The described potsherd was found in 1981-1983 in horizon 'b' of the 'Neolithic' level of the Pugach 1 site excavated by Tovkaylo on the left bank of the South Buh River, close to the town of Yuzhnoukrainsk, in the Arbuzinka district of the Mykolaiv area of Ukraine. Horizon ' $b$ ' contains a mix of artefacts of the Neolithic Bug-Dniester and the Eneolithic Trypillia cultures (Tovkaylo 2005.68).

Another vessel with Cardium decoration was found at the Pidgorivka site in the eastern part of the Northern Black Sea area. It appeared in a figure drawn by Sergiy Telizhenko and published in the monograph
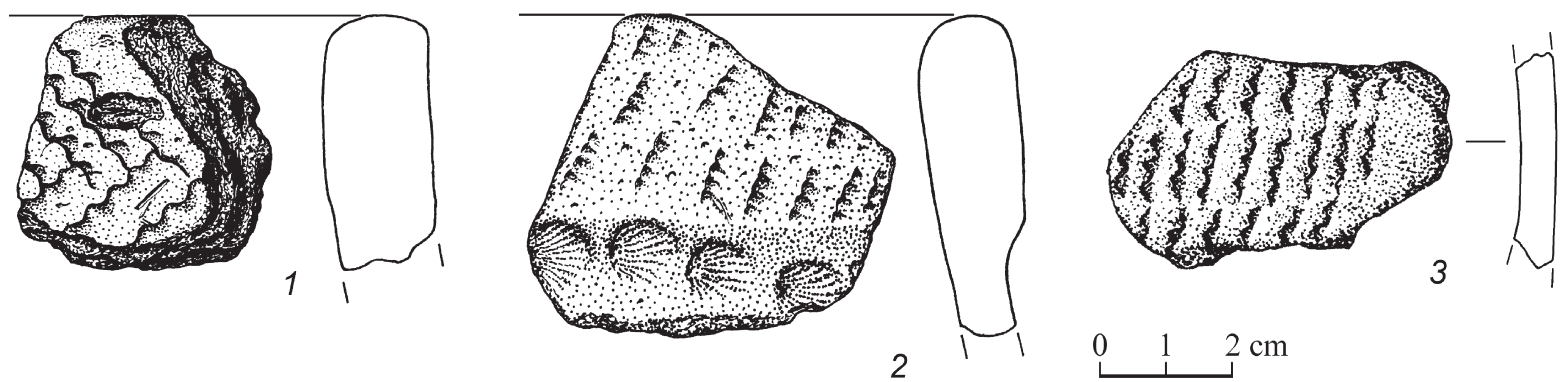

Fig. 1. Pottery with Cardium decoration from Neolithic sites of the Northern Black Sea area. 1 Savran'. 2 Pugach 1 (after Tovkaylo 2005.130, Fig. 48.3). 3 Pidgorivka (after Man'ko 2006.250, Fig. 130.3). 
of Valery Man'ko (Man'ko 2006.250, Fig. 130.3). Man'ko didn't recognize it as a representative of $\mathrm{Car}$ dium ware. One fragment of a wall of the vessel decorated with three horizontal rows of sub-vertical imprints made with the edge of a Cardium shell is shown in the figure (Fig. 1.3). I have not examined it, so the details of its technological characteristics are not known to me. According to information kindly provided by Sergiy Telizhenko, it contains an admixture of crushed cockleshell.

The Pidgorivka site was discovered by Vladislav Gladilin in 1963 and investigated by Yury Gurin in 1980s and Sergiy Telizhenko in 2002 and 2007. It is situated on the former left (nowadays - right) bank of the Aydar River, a tributary of the Siversky Donets, between Pidgorivka village and the town Starobil'sk in the Starobil'sk district of the Lugansk area. Gurin, who found the above-described sherd, attributes the Neolithic materials at the Pidgorivka site to the Lower-Don culture (Gurin 1992). The vegetal temper based radiocarbon dating shows the date to $6050 \pm 90$ uncal BP (Ki-9439-40) (Man'ko 2006.250).

Thus, the presence of Cardium pottery in the Northern Black Sea area is an evident fact. The gradual appearance of further potsherds with Cardium decoration in old collections from Neolithic sites in the region has become a consistent trend since the present author's publications. However, the number of such sites and the finds in collections are far from enough. The most probable explanation for the presence of this material is that these vessels were imported, which allows us to raise the question of where in the region these ceramics originated.

\section{The origin of Cardium pottery in the Northern Black Sea area}

As we know, the spread of Cardium pottery in the Mediterranean was related to maritime navigation. A large majority of the respective finds were discovered directly on the seashore or nearby, whereas in the Northern Black Sea area all vessels with Cardium decoration have been found at considerable distances from the modern coastline - approximately $185 \mathrm{~km}$ for Savran', $130 \mathrm{~km}$ for Puhach 1 , and $220 \mathrm{~km}$ for Pidgorivka (Fig. 2). Also, it should be noted that the level of the Black Sea was approximately $10 \mathrm{~m}$ lower than today, and there was a lagoon of the Don River in the 7-6th millennium calBC which is now the area of the modern Azov Sea. Accordingly, the ancient marine coastline was still farther from the sites. Nevertheless, it is proposed that the Car- dium vessels of Savran', Puhach 1, and Pidgorivka are also imports from a coastal area. There is some 'hard' evidence in the archaeological record to argue for it.

As noted earlier, the raw material of some vessels with Cardium decoration from Savran', Puhach 1, and a few other sites of the steppe part of the South Buh River basin contained large quantities of $\mathrm{Cypri-}$ deis torosa littoralis valves. These ostracods live in waters with wide ranges of salinity, from almost fresh to hypersaline, but they occur in great numbers in brackish water with salinity between 2 and $16 \%$. They prefer the quiet waters of inland lakes, as well as bays, fjords, lagoons, river mouths, deltas, and other marginal marine environments with depths to $30 \mathrm{~m}$, and slimy and sandy-slimy bottoms. They are widely distributed, being found on all seashores of Europe, the Mediterranean coasts of the Middle East and North Africa, lakes of Central Africa, and Central Asia. They are widely present both in the ancient and modern fauna of the Black Sea (Athersuch, Horne and Whittaker 1989.114; Opreanu 2003.74). Consequently, sand that was supersaturated with these valves could have come from a sea or lagoon beach.

Initially, Tovkaylo was sceptical about the presence of Cardium pottery on the northern coast of the Black Sea. Therefore, he supposed that the Cardium shells used for decorating some Neolithic vessels from the steppe region of South Buh River basin, and also the remains of Cyprideis torosa littoralis in their raw material, came from local tertiary deposits, outcropping on a surface of the southern slopes of the Podolian upland. To check this supposition, he collected samples of tertiary sediments in gullies within a radius of $10-15 \mathrm{~km}$ from the Puhach 1 site, but these yielded neither Cardium nor Cyprideis torosa littoralis valves (Tovkaylo, personal communication).

Thus, new facts discovered in recent years can indirectly indicate the presence of Neolithic settlements with Cardium pottery on the northern coast of the Black Sea. It is necessary to link their origin to the same processes that spread Cardium pottery along the coast of the Mediterranean. The dating of the Pidgorivka site to the end of the $6^{\text {th }}$ millennium calBC confirms the synchronicity of North-Pontic Cardium pottery and the period of its most wide distribution in the Mediterranean.

However, no Neolithic settlement in the coastal zone of the Northern Black Sea area is known. This is pro- 


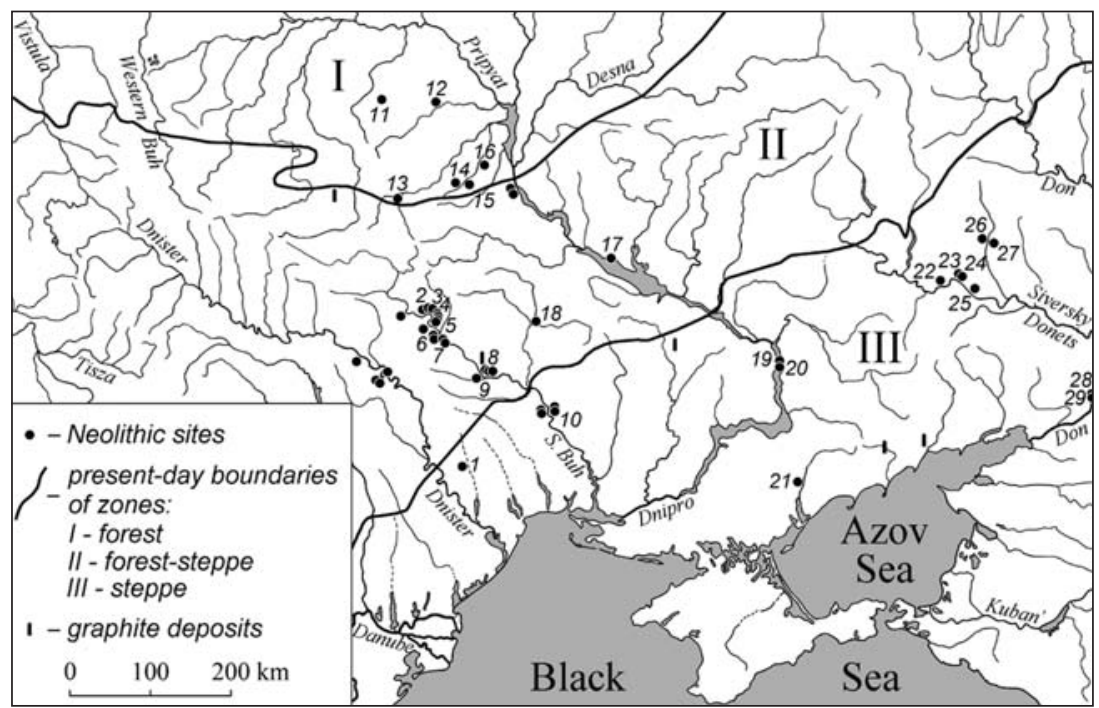

Fig. 2. The location of sites with 'Samchyntsi' pottery and its derivatives. Only the sites mentioned in the article are numbered. 1 Ghirzhove. 2 Samchyntsi 1. 3 Samchyntsi 2. 4 Schurivtsi-Porig. 5 Sokiltsi 6. 6 Ladyzhin 2. 7 Baz'kiv Ostriv. 8 Zhakchyk. 9 Savran'. 10 Pugach 1. 11 Korma 1B. 12 Krushnyky. 13 Gyrlo Gnylopyati. 14 Lazarivka. 15 Zavalivka. 16 Borodyanka 3V. 17 Mutykhi. 18 Dobryanka 1. 19 Strilcha Skelya. 20 Kizlevy Ostriv 5. 21 Semenivka 1. 22 Zlyvki. 23 Zelena Gornytsya 5. 24 Zelena Gornytsya 6. 25 Tuba 2. 26 Pidgorivka. 27 Starobil'sk. 28 Razdorskoe 1. 29 Rakushechny Yar.

bably the consequence of the submergence of the Neolithic coastline with the rise of the Black Sea over the last eight thousands years.

\section{The problem of coastal Neolithic sites}

The submersion of coastal archaeological sites younger than 125000 and older than 5000 years due to glacial-eustatic processes took place on most coastlines of the world. According to some estimates, some $80-90 \%$ of evidence of past coastal activities are now submerged (Flemming 2004.1226). The submersion of Neolithic settlements by sea and estuaries is also characteristic of most of the Mediterranean region. However, the discovery and thorough research of such settlements (Leucate-Corrège, AtlitYam) have been a matter of luck rather than the result of systematic exploration (Guilaine et al. 1984; Galili et al. 1993).

Coastal sites that have not been submerged are also not always accessible for archaeological research. Because of the rise in global sea levels, river mouths where Neolithic settlements were often located have become gulfs. Continuous fluvial dynamics have formed new deltas, and even Neolithic sites situated at higher elevations came to lie under thick layers of alluvial sediments (Brückner et al. 2005), making their discovery practically impossible in such cases.
Discoveries sometimes occur accidentally. For example, $5^{\text {th }}$ millennium calBC finds were found at a depth of $7 \mathrm{~m}$ relative to a modern land surface at the Minshat Abu Omar site in the Nile delta, but only because of geological drilling (Shirai 2010.9, 10). Another striking example is the Yenikap1 site at the mouth of the Bayrampaşa River in the centre of Istanbul. It was discovered only owing to the tube tunnel construction for the Marmaray high speed train under the Bosphorus. Its Neolithic $7^{\text {th }}$ millennium calBC layer lies in a stratum of alluvium $6 \mathrm{~m}$ below the present level of the Sea of Marmara (Algan et al. 2009).

With the foregoing as background, the likelihood of discovering Neolithic settlements on the shoreline of the Northern Black Sea area in the near future is improbable. This is due to both the submergence of ancient seashores and the sedimentation of thick alluvium in the deltas and lower reaches of large rivers debouching into the sea: the Danube, Dnister, South Buh, Dnipro, Don, Kuban rivers. There is a better chance of finding such sites on the south coast of the Crimea only. Because of the presence of the Crimean Mountains, the Holocene rise in sea level had almost no effect on the outlines of the coast in this region, a landscape which resembles that of Provence and the Côte d'Azur.

The absence of Neolithic sites in the modern coastal zone of the Northern Black Sea area does not mean that there was no ancient population in this region of plentiful food resources: animals, waterfowl and fish. In my opinion, the presence of a population is indirectly confirmed by the imported vessels with Cardium decoration described above, which were discovered far to the north. Consequently, investigating the Neolithic of the Northern Black Sea area, we must always bear in mind the population that is 'lost' to research. Against the background of the foregoing idea, there is an opportunity to review the Neolithic in the region as a whole and attempt to find some other, probably less obvious, indirect traces of participation of the hypothetical coastal popu- 
lation in cultural, social, demographic processes 89 thousand years ago. The character of these indirect traces can cast light on the character of the material culture of the same coastal population, the settlements of which are unavailable to excavation today.

\section{'Samchyntsi' pottery and its origin}

To expose possible traces of influence of the hypothetical coastal Neolithic on the Neolithic of the interior regions of the Northern Black Sea area, I have studied processes and phenomena which have no logical explanation within the framework of existing concepts of development of the local Neolithic. The most striking of such phenomena are ceramics of the so-called 'Samchyntsi' type.

'Samchyntsi'-type pottery was defined by Valentin Danilenko in 1958. Its name originates from the Samchyntsi 1 and Samchyntsi 2 sites investigated by Pavlo Khavlyuk and Danilenko on the left bank of the South Buh River, close to Samchyntsi village, in the Nemirov district of the Vinnitsa area in 19561958 (Danilenko 1969.118, 119).

Sketching in the broad outlines, 'Samchyntsi' pots had rounded and pointed bottoms, with slightly Sshaped, cylindrical, and oblong spherical bodies. In most cases, they were made from raw material with an abundant coarse-grained mineral admixture of quartz and feldspar gruss and a small admixture of fibrous organic remains; it rarely included graphite and micaceous sand and crushed cockleshells. External surfaces are usually slightly burnished and most frequently dark grey or dark brown, and less often the colour is fulvous or reddish. The decoration is present almost on all vessels, most frequently on the upper half of the pot. The specific decoration of 'Samchyntsi' ware consists of elongated imprints of a notched stamp, and narrow superficial lines made with the same stamp, and frequent decoration of the internal edge of pottery rims by notched stamp impressions or lines. Usually, a few lines of the imprints form a continuous encircling horizontal belt or vertical zone. Frequently, some of these belts or zones are separated from one another by a horizontal or diagonal lines, or lines which form a herringbone or sinuous composition (Figs. 3-5). Vessels are rarely decorated only with narrow superficial lines which form a grid or some more irregular angular figures.

All the researchers writing on 'Samchyntsi' pottery have long repeated Danilenko's opinion. According to his periodisation, the presence of this ware on the site was a sign of its affiliation with the 'Samchyntsi' phase of the Bug-Dniester culture. The dating of this phase was defined by two imported Linear-Band Pottery culture vessels found together with the 'Samchyntsi' pots in the Baz'kiv Ostriv site on an island in the middle of the South Buh River. Danilenko connected the origin of 'Samchyntsi' pottery with a northern impulse from the upper reaches of the Dnipro after the long period of domination of Criş culture influence in the area of the Bug-Dniester culture (Danilenko 1969.36, 153).

At first sight, Danilenko's theory seemed to be confirmed by the presence of some 'Samchyntsi' vessels on sites of the Dniepro-Donets culture (Lazarivka, Krushnyky, Zavalivka etc.) and the Pripyat-Neman culture (Gyrlo Gnylopyati, Korma 1B, Borodyanka $3 \mathrm{~V}$ ) in the Kyiv and Zhitomir areas of Ukraine (Neprina 1969.135, Figs. 1.2, 3; Zaliznyak, Balakin and Okhrimenko 1987.69, Figs. 4.10, 12; Zaliznyak 1998 .

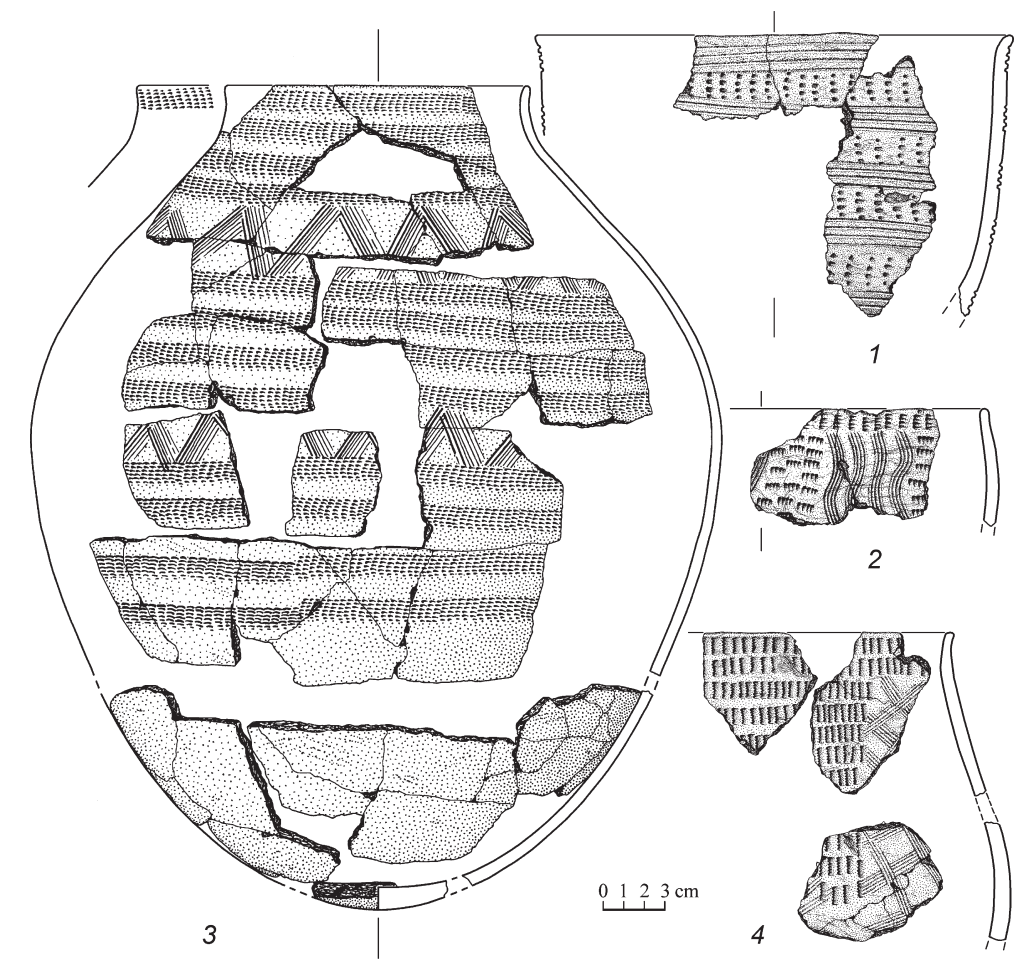

Fig. 3. The 'Samchyntsi' pottery. 1, 2 Sokiltsi 6. 3 Samchyntsi 1. 4 Baz'kiv Ostriv. 


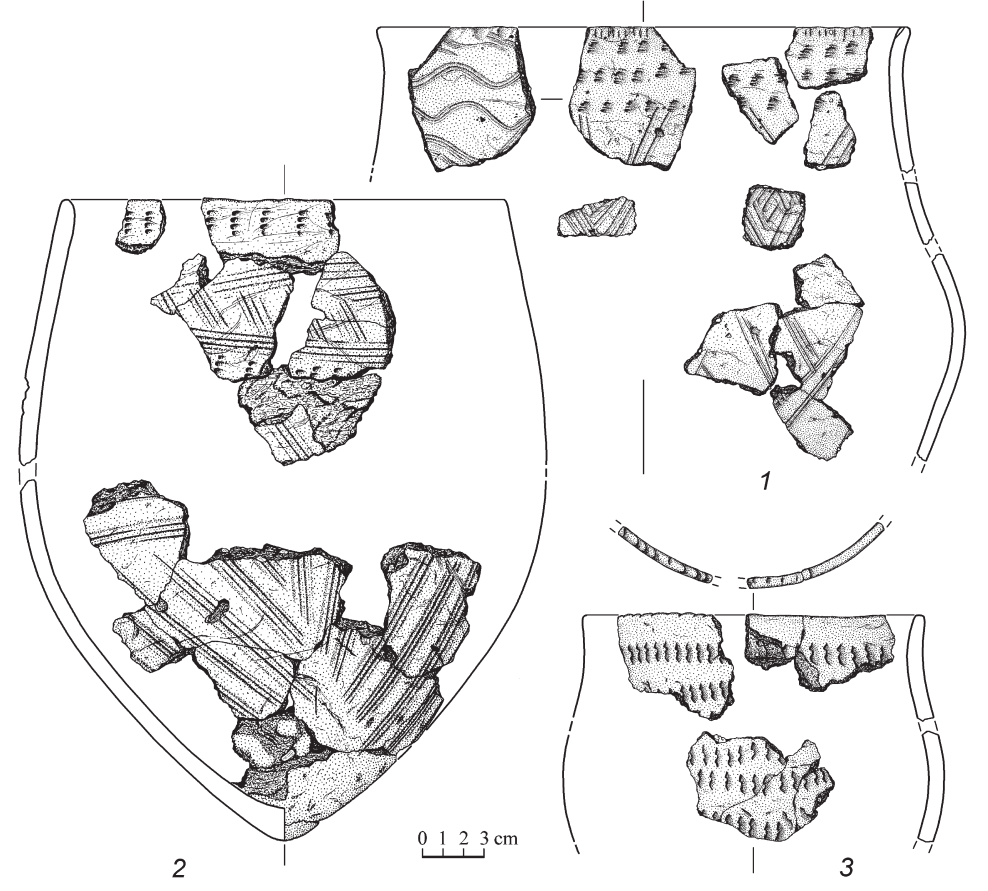

Fig. 4. The 'Samchyntsi' pottery. 1 Ladyzhin 2. 2 Schurivtsi-Porig. 3 Baz'kiv Ostriv.

233, Fig. 91; Gaskevych 2001.45, 46, Figs. 5.16, 18, 6.27-32). However, they are more rare here than in the forest-steppe area. The decoration looks poorer and more monotonous than on the material from the southern sites. Moreover, the raw material of a few of these vessels contains an admixture of graphite, the main deposits of which are found in the south - in the Northern Black Sea area (Fig. 2). These facts lead one to consider these finds as an effect of the influence from south to north, but not vice versa. Nadezhda Kotova was the first to understand this some 20 years ago (Kotova 1994.77, 78). She therefore offered her own hypothesis on the origin of 'Samchyntsi' ceramic traditions: in her opinion, a Neolithic population moved from the area of the LowerDon culture, bringing the ceramic traditions to the BuhDnister area (Kotova 1994. 53, 54, 77; 1998.182, 184).

Indeed, several vessels with decoration very similar to the 'Samchyntsi' were also found east of the area of Bug-Dniester culture in the forest-steppe part of the Dnipro River basin (Dobryanka 1, Mutykhi sites), the Dnipro rapids region (Semenivka 1; Kizlevy Ostriv 5; Strilcha Skelya sites), the Siversky Donets River basin (Starobil'sk; Tuba 2, Zelena Gornytsya 5; Zelena Gornytsya 6; Zlyvki sites), and the Lower Don region (Razdorskoe 1, Rakushechny Yar sites) (Telegin, Titova 1998.142, Fig. 42.19; Belanovskaya 1995.100-116; Kotova 2002.129, 134, 136, 196, 202, 230, Figs. 5.2, 3, 13, 14, 10.3, 12.1-3, 7, 72.1, 2, 78.2, 5, 106.3; Zaliznyak, Man'ko 2004.161, Fig. 8.1; Tuboltsev 2005; Man'ko 2006.162, 165, 205-206, 221-232, Figs. 42, 45, $85.1,86.2,101-112)$.

However, Kotova could not explain the sources of the pottery of the Lower-Don culture per se. Her sole assumption connects its origin with the Early Neolithic of the Urals region. But the Isetskoe right-bank site - the only site, material of which was used to illustrate the hypothesis - is situated in Asia, far to the east of the Urals in the Sverdlovsk area of Russia, a distance of some $1700 \mathrm{~km}$ from the Rakushechny Yar site. In so doing, the researcher recognised that similar pottery is absent from the steppes to the east of the Don River. She explained this fact by the single migration of a group of Neolithic population of the Ural region to the Azov region which left no traces en route (Kotova 1998.182, 183).

The results of the radiocarbon dating of a great number of East European Neolithic sites received in the Kyiv radiocarbon laboratory (Ki-) in the last fifteen years conclusively confirm the native North Pontic

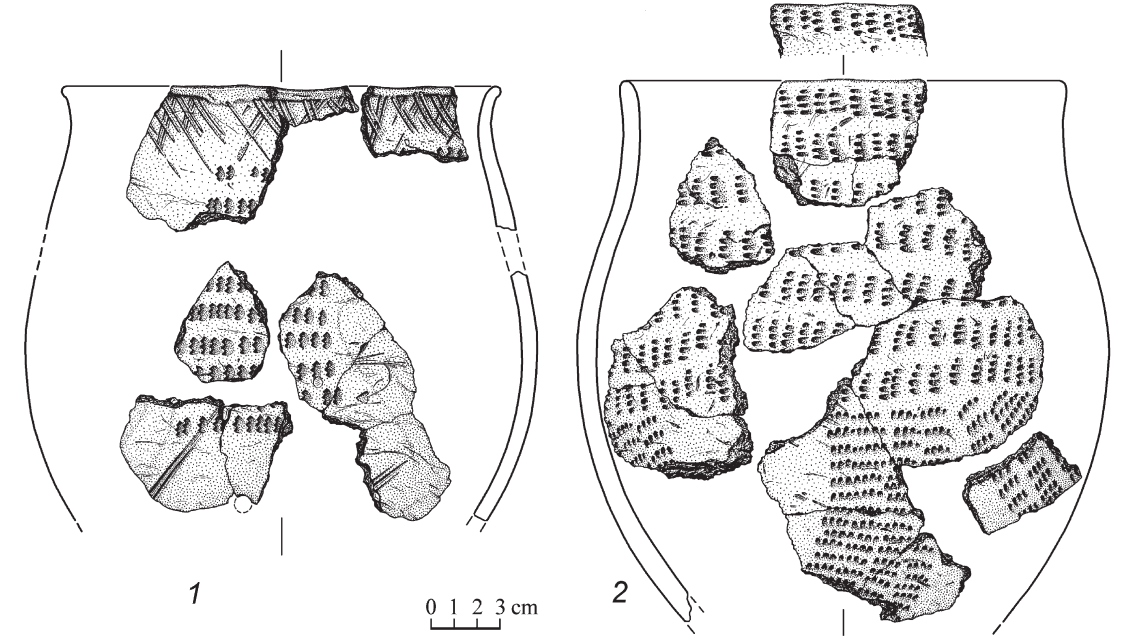

Fig. 5. The 'Samchyntsi', 1 Baz'kiv Ostriv. 2 Schurivtsi-Porig. 
origin of 'Samchyntsi' pottery. It should be noted that the absolute age of these dates has been repeatedly called into question (Tovkaylo 2005.44-49; Zaliznyak 2005.125; Gaskevych 2007; Kadrow 2007. 254). However, comparison of these dates among themselves can be used for relative comparison of the age of the sites, as all of the dates were obtained by one method in one laboratory.

'Samchyntsi' pottery is known from multiple sites in the Buh-Dnister area. These sites date from the middle of the $7^{\text {th }}$ millennium calBC to the beginning of the $5^{\text {th }}$ millennium calBC, according to the Kyiv laboratory (Videyko, Kovalyukh 1998; Kotova 2002. 103, 104; Tovkaylo 2010.214). But Neolithic vessels of other specific types were found mixed up with the 'Samchyntsi' ones in the overwhelming majority of cases. Therefore, no one can be sure that these dates give the exact age of the 'Samchyntsi' ceramics. There are only five sites with representative collections which contained only 'Samchyntsi' pottery - Samchyntsi 2, Schurivtsi-Porig, Ladyzhin 2, Zhakchyk, and Ghirzhove. The radiocarbon dates from the Kyiv laboratory are for the Ghirzhove site only (Tab. 1), which is the southernmost of them (Fig. 2). The site is situated in the steppe zone between the Buh and Dnister rivers on the bank of the Kuchurgan River (the left tributary of the Dnister) close to Ghirzhove village, in the Velyka Myhailivka district of the Odessa area. The distance to the modern coast of the Black Sea is approximately $95 \mathrm{~km}$. This site was researched by Pavel Boriskovskiy and Vladimir Stanko in 1961-1963 (Stanko 1966; 1967).

The pottery with imprints of a notched stamp and lines drawn by such stamps is casually mentioned by Tatyana Belanovskaya among the finds of the bottom layers of the Rakushechny Yar site (Belanovskaya 1995.100-109). These layers are older than at the Ghirzhove site, because they are dated to the first half/middle of the $7^{\text {th }}$ millennium calBC by the Kyiv laboratory (Tab. 2).

On the other hand, for the earliest dated sites with 'Samchyntsi' pottery in the forest part of the Dnipro
River basin, the dates are from the first half and middle $6^{\text {th }}$ millennium calBC (Tab. 3).

These data testify to the inconsistency of Danilenko's hypothesis about the northern origin of 'Samchyntsi' pottery.

According to the dates from the Kyiv laboratory, the Koksharovsky Kholm and Nizhnee Ozero 3 sites, with comb decorated pottery of the Middle and Southern Trans-Ural regions are dated no earlier than the mid-6th millennium calBC (Chairkina 2009.180, 181; Shorin 2009.177), showing the inconsistency of Kotova's hypothesis about the Urals origin of 'Samchyntsi' ornamental traditions also.

Thus all the facts testify that 'Samchyntsi' pottery appeared in the south of the Northern Black Sea area. From the beginning, it was characterised by rich decoration and perfect making. No analogues are known in the neighbouring Neolithic cultures of the East Balkans, the Lower Danube region, or the Caucasus. Therefore, one has the impression that it originated 'from nowhere'. Then, during the following two thousand years, it spread northward over the territory of modern Moldova and the greater part of the territory of modern Ukraine.

In my opinion, the inhabitants of what are now the submerged coastal Neolithic settlements of the Northern Black Sea area could have been the initial source of distribution of 'Samchyntsi' ceramic traditions. The same arguments, as in the case with Cardium pottery, provide evidence to support this thesis. According to Tovkaylo, there are remains of the ostracod Cyprideis torosa littoralis in the raw material of some vessels with notched stamp imprints from the Neolithic sites of the steppe part of the South Buh River basin. So, ordinary notched imprints could have been made with the slackly pressure of the sinuous edge on the interior surface of a Cardium shell, and elongated notched imprints could have been made with the edge of the external surface with radiating ribs on the same shell when placed at an acute angle to the surface of the vessel. The paral-

\begin{tabular}{|lcccccc|}
\hline Site name & $\begin{array}{c}\text { Lab. } \\
\text { Number }\end{array}$ & Material & Date BP & $\begin{array}{c}\text { Calibration date } \\
\text { range BC* } \\
\text { (1 sigma) }\end{array}$ & $\begin{array}{c}\text { Calibration date } \\
\text { range BC } \\
\text { (2 sigmas) }\end{array}$ & Reference \\
\hline Ghirzhove & $\mathrm{Ki}-11240$ & bone & $7390 \pm 100$ & $6400-6100$ & $6440-6060$ & Man'k0 2006.19 \\
\hline Ghirzhove & $\mathrm{Ki}-11241$ & pottery inclusions & $7280 \pm 170$ & $6360-6000$ & $6500-5800$ & Man'ko 2006.19 \\
\hline Ghirzhove & Ki-11743 & pottery inclusions & $7200 \pm 220$ & $6350-5840$ & $6500-5650$ & Man'ko 2006.19 \\
\hline
\end{tabular}

Tab. 1. Radiocarbon dates of the Ghirzhove site. *Calibrated by OxCal 3.10 (Bronk Ramsey 1995; Reimer et al. 2004). 
A new approach to the problem of the Neolithisation of the North-Pontic area

\begin{tabular}{|lcccccc|}
\hline Site name & $\begin{array}{c}\text { Lab. } \\
\text { Number }\end{array}$ & Material & Date BP & $\begin{array}{c}\text { Calibration date } \\
\text { range BC } \\
\text { (1 sigma) }\end{array}$ & $\begin{array}{c}\text { Calibration date } \\
\text { range BC } \\
\text { (2 sigmas) }\end{array}$ & Reference \\
\hline $\begin{array}{l}\text { Rakushechny } \\
\text { Yar, layer 20 }\end{array}$ & Ki-6476 & pots-snuff & $7930 \pm 140$ & $7040-6660$ & $7200-6450$ & Telegin et al. 2000 \\
\hline $\begin{array}{l}\text { Rakushechny } \\
\text { Yar, layer 20 }\end{array}$ & Ki-6477 & pots-snuff & $7860 \pm 130$ & $7030-6590$ & $7100-6450$ & Telegin et al. 2000 \\
\hline $\begin{array}{l}\text { Rakushechny } \\
\text { Yar, layer 20 }\end{array}$ & Ki-6475 & pots-snuff & $7690 \pm 110$ & $6640-6440$ & $6900-6250$ & Telegin et al. 2000 \\
\hline
\end{tabular}

Tab. 2. Radiocarbon dates of the bottom layers of the Rakushechny Yar site.

lel lines could also have been drawn with the sinuous edge of the same shell (Figs. 6, 7).

\section{The Neolithisation of the Northern Black Sea area - a new approach}

If our hypothesis on the origin of 'Samchyntsi' pottery is correct, it considerably changes traditional ideas about the Neolithisation process in the Northern Black Sea area. Neither of the hypothetical scenarios for the Neolithisation of this area mentioned at the beginning of the article can be completely confirmed by the archaeological record.

So, the overland spread of Neolithic innovations from the Balkans in the Northern Black Sea area could not have begun before approximately 6100 calBC, when the first farmers appeared in the territory of modern Romania (Biagi, Shennan and Spataro 2005; Biagi, Spataro 2005). The presence of the Pre-Pottery Neolithic in the Caucasus is now being discussed (Badalian et al. 2004.404; Kiguradze, Menabde 2004.361; Connor, Sagona 2007.27, 28). But all of the already quite abundant radiocarbon dates for the pottery Neolithic of Transcaucasia (Goytepe; Aratashen, level II; Aknashen-Khatunarkh, horizon III-V; Kamiltepe; Aruchlo; Gadachrili Gora), and the Northern Caucasus (Cmi, horizon 3) fall into the $6^{\text {th }}$ millennium calBC (Badalyan et al. 2007; 2010.210; Aliyev, Helwing 2009.38; Hansen, Mirtskhulava and Bastert-Lamprichs 2009.22; Guliev, Gusejnov and Almamedov 2009.30; Rostunov, Ljachov and Reinhold 2009.65; Kvavadze, Jalabadze and Shakulashvili 2010). According to palynological and paleoclimatological data, Neolithic layer ' $C$ ' at the Chokh site in the Eastern Caucasus was formed in more humid conditions than today. On this basis, it was correlated with the New Caspian transgression and dated to the beginning of the $6^{\text {th }}$ millennium calBC (Amirkhanov 1987.27-31). New research of sediment records of eleven lakes with reliable chronologies and robust proxies from arid Asian regions fully confirms this conclusion (Chen et al. 2008). However, the radiocarbon dates of the earliest Neolithic sites of the Northern Black Sea area are older. This can partly be explained by the imperfection of the dates from the Kyiv laboratory derived from samples of potsherds, which has been noted repeatedly.

In any case, the prototypes of most types of early Neolithic pottery of the Northern Black Sea area are unknown in the Neolithic of the Eastern Balkans, the Carpathian-Danube region, and the Caucasus. This holds not only for 'Samchyntsi' pottery with notched stamp imprints, but also for some types of pottery with flat and conical bottoms decorated with a stroked pin-action and drawn linear techniques, not considered in detail here. Indeed, all the types of pottery mentioned so far are - formally - Impresso ware, in so as far as they have printed decoration. The Cardium pottery - finds of which are already well-attested in the region - is also a variety of Impresso ware. Thus, the Neolithic with the Impresso ware of the Mediterranean is the closest analogy to this pottery in the Northern Black Sea area.

\begin{tabular}{|c|c|c|c|c|c|c|}
\hline Site name & $\begin{array}{l}\text { Lab. } \\
\text { Number }\end{array}$ & Material & Date BP & $\begin{array}{l}\text { Calibration date } \\
\text { range BC } \\
\text { (1 sigma) }\end{array}$ & $\begin{array}{c}\text { Calibration date } \\
\text { range } \mathrm{BC} \\
\text { (2 sigmas) }\end{array}$ & Reference \\
\hline Lazarivka & $\mathrm{Ki}-9840$ & $\begin{array}{c}\text { pottery } \\
\text { inclusions }\end{array}$ & $6900 \pm 150$ & $5980-5660$ & $6100-5500$ & Man'ko 2006.16 \\
\hline $\begin{array}{l}\text { Gyrlo } \\
\text { Gnylopyati }\end{array}$ & $\mathrm{Ki}-8691$ & $\begin{array}{c}\text { pottery } \\
\text { inclusions }\end{array}$ & $6490 \pm 90$ & $5530-5360$ & $5620-5300$ & Man'ko 2006.16 \\
\hline
\end{tabular}

Tab. 3. Radiocarbon dates of the Lazarivka and Gyrlo Gnylopyati sites. 
The similarity between some types of Early Neolithic ware from Eastern and Western Europe has been noted recently. However, this similarity has been explained by a wave of initial pottery making spreading from sources located in the east of the steppe zone, approximately from the lower Volga-Ural interfluves, far to the west, reaching the western confines of Europe (sites of the La Hoguette, Limbourg, 'Epicardial' and Roucadour groups) (Dolukhanov, Mazurkevich and Shukurov 2009.249-251). In my opinion, as the Black Sea, through the Bosphorus, the Sea of Marmara and Dardanelles, is connected with the Mediterranean, and local Neolithic pottery is a kind of Impresso ware, the whole local Neolithic of the Northern Black Sea area might be interpreted as a separate north-eastern branch of the Mediterranean circle of Neolithic cultures with Impresso ware (Gaskevych 2009; 2010). If this is true, identical mechanisms of Neolithisation could have been at work in both the Northern Black Sea area and the Northern Mediterranean region.

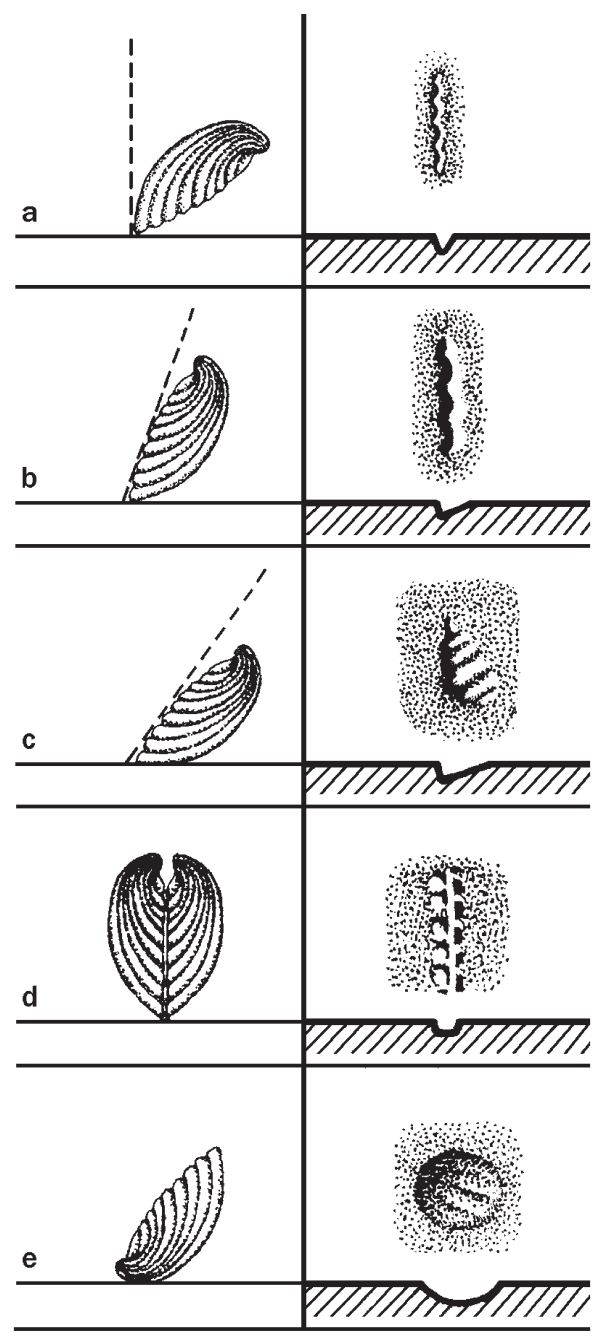

Fig. 7. Various techniques of the imprinting by a Cardium shells (after Brandaglia 2002.416).

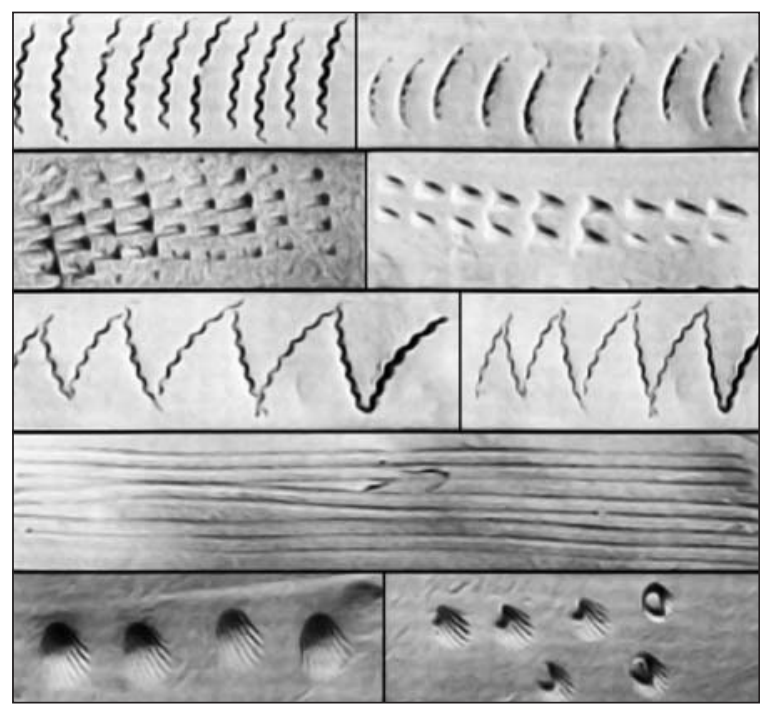

Fig. 6. Types of the decoration made by Cardium shells (after Manen 2002. 126, Fig. 3).

The spread of the Neolithic with Impresso ware in the Mediterranean has the character of so-called 'leapfrog colonisation', carried out by coastal navigation. Some evidence suggests that it occurred very quickly - at a rate of $4.5 \mathrm{~km} / \mathrm{year}$ in the southern part of the Adriatic (Forenbaher, Miracle 2005.521), and 10$20 \mathrm{~km} /$ year in the Western Mediterranean from the Gulf of Genoa to the estuary of the Mondego River (Zilhão 2001.14184)

Similar parameters of average advection rates $10 \mathrm{~km} /$ year along the coast and $5 \mathrm{~km} /$ year along the valleys of two major European rivers, the Danube and Rhine - have been used in a mathematical model of the population dynamics of the spread of incipient farming in Europe developed by archaeologists and mathematicians at the University of Newcastle upon Tyne. The model also allows for diffusivity of space, which gradually declines with increasing distance from a coastline and with increasing altitude, and disappears completely at $1000 \mathrm{~m}$ above sea level (for details, see: Davison et al. 2006.644647). The results of this modelling for well investigated regions of South-Eastern, Central and Western Europe appear close to the results obtained by archaeological research. Therefore, there is reason to believe that the results for the Northern Black Sea area are also correct.

The modelling shows the rapid spread of Neolithic innovations from the west to east along the western and northern coast of the Black Sea. The simulated time for the beginning of Neolithisation in the region corresponds to the time when the process began in the south of the Balkan Peninsula and the coasts of 
the southern Adriatic (Davison et al. 2006.648, Fig. 4). The reliable radiocarbon dates assigned to the earliest sites from Thessaly, Macedonia (Achilleion, level Ia, Ib; Argissa; Nea Nikomedeia; Sesklo, level of the 'The Earliest Pottery Neolithic'), and Corfu (Sidari C bottom) are no earlier than c. 6600 calBC (Perlès 2001. 99-110). In general, the results are close enough to the actual dates of the Early Neolithic of the Northern Black Sea area from the Kyiv laboratory. The simulated Neolithisation process spreading along the opposite southern and eastern coasts of the Black Sea did not extend to the North Pontic region (Fig. 8).

It is intriguing that the first appearance of some other similar groups of artefacts is a little earlier in the Northern Black Sea area compared

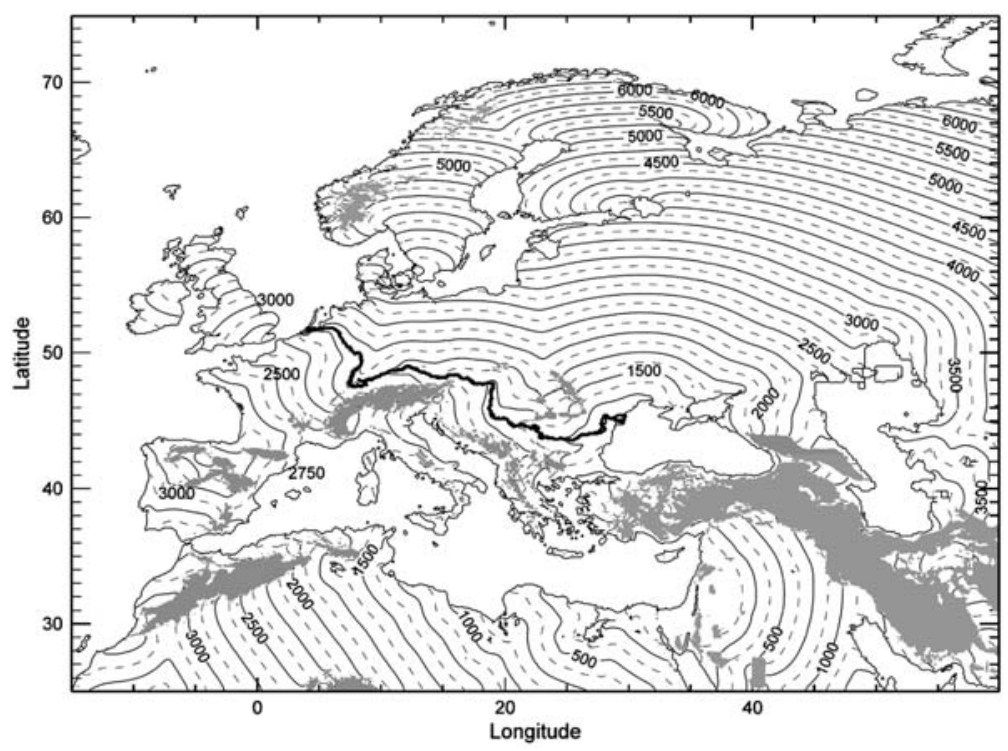

Fig. 8. An isochron map of simulated Neolithic dispersal from one centre at the Jericho settlement with consideration for faster spread along the Danube-Rhine corridor and coastlines. Regions inaccessible to the population (where altitude exceeds $1000 \mathrm{~m}$ ) are filled with grey. The latitude and longitude scales are given in degrees (after Davison et al. 2006.648, Fig. 4). to Mediterranean Europe. For example, the parallelsided blades and isosceles and rectangular trapezes industries appeared in the Northern Black Sea area in first half $8^{\text {th }}$ millennium calBC (Biagi, Kiosak 2010), and on Sicily, in the south of the Italian peninsula and, probably, on the south-eastern coast of the Adriatic only around 7000-6600 calBC (Perrin et al. 2010).

One more striking example is the so-called 'transverse grooved stones', often called 'chovnyky' in Ukrainian literature and 'chelnoki', 'utyuzhki', or 'poliroval'niki' in Russian. Their initial area was in the Near East, where they have been found in Epipalaeolithic and Protoneolithic complexes of the $10^{\text {th }}$ to the first half of the $8^{\text {th }}$ millennium calBC ( $S O$ lecki, Solecki 1970.834-836; Wechler 1997a; 1997b). These artefacts existed on the Mediterranean coast of North Africa, the Trans-Caucasus, the Northern Black Sea area, and Central Asia in the 7-6th millennium calBC. In the 5-4th millennium calBC, their distribution was displaced east and covered the forest-steppe and the steppe zone from the Dnipro River in the west to the Ob' River in Siberia in the east, and also a small area in the interfluves of the Amu Darya and Syr Darya rivers in Central Asia (Usacheva 2005.15, 16, Figs. 3, 4). Similar artefacts occasionally occur in materials from Western Mediterranean sites with Cardium - Impresso pottery of the $6-5^{\text {th }}$ millennium calBC also. For example, a typical transverse grooved stone was found at the Va- lada do Mato site in the interior of Southern Portugal which is dated to the first quarter of the $5^{\text {th }}$ millennium calBC (Diniz 2007.151). The researcher, Mariana Diniz, interpreted this find as a 'hone of amphibolite, with a groove' and considered that it was used for making stone, bone or cockleshell personal ornaments (Diniz 2007.109, 249, 291, Figs. 15.4, Photo 41). The important point is that the Valada do Mato site was settled by people with a mixed economy having cultural traits of both the Mesolithic and Neolithic cultural packages (Diniz 2007. 156-164). No such combination of traits has been found in synchronous Neolithic sites in Portugal, but they are characteristic of practically all Neolithic sites of the 7-6th millennium calBC in the Northern Black Sea area.

On the one hand, the similarity of some processes and the distribution of similar groups of artefacts can confirm that the Neolithic with Impresso ware of the North-Mediterranean and North Pontic areas were two parts of a single cultural circle. On the other hand, the asynchronism of the beginning and progress of these processes and the existence of original traits in the Neolithic of the mentioned areas is evidence against regular direct contacts of their population. In addition, such contacts could have been hampered, as the area of the Anatolian and Balkan Neolithic groups with other cultural traditions (Karanovo-Starčevo-Körös-Criş complex) divided them geographically. At first, there probably 
was a common origin and similar mechanisms of Neolithisation in both remote regions, and separate development later. The common characteristics typical of the whole area of the Great Mediterranean Neolithic with Impresso ware indicate that its origin can be related to the same groups having available the economic achievements of the Near-Eastern Early Neolithic and traditions of pottery making of the Sahara-Sudanese Neolithic of North Africa ( $\mathrm{Ga}$ skevych 2010.238-241).

For all these reasons I have proposed a third hypothetical scenario of Neolithisation in the Northern Black Sea area in addition to the two available, which proposes that Neolithisation in the region began with a process of demic diffusion consisting of the rapid spread of small Mediterranean seafaring communities along its coastline in the first half or the middle of the $7^{\text {th }}$ millennium calBC. Their beachhead colonies are probably submerged now. The process of cultural diffusion, when some elements of the 'Neolithic package' were adopted by local Mesolithic populations began afterwards. A possible consequence of this is the occurrence of the first pottery with decoration using pin-action and comb stamp impression techniques, and also the polished stone artefacts and livestock in inland territories. The evidence of direct contacts of interior groups with their coastal neighbours is the pottery found far from the sea, but made of sand with the remains of brackish water ostracods, and decorated by marine cockleshells prints. Simultaneously, the first farmers of the Balkan region and the Carpathian-Danube basin, who were of Anatolian origin, migrated overland from the west to the Northern Black Sea area. As a result, the Neolithic of the Dnister and South Buh river basins became syncretic. It combines traits of the early Danubian Neolithic and the Mediterranean Neolithic with Impresso - Cardium pottery (Bug-Dniester culture). In the remaining territory of the Northern Black Sea area, traditions based on the cultural complex of the Mediterranean maritime migrants continued to develop.
I again draw attention to the preliminary character of this idea. Unfortunately, at present it is based on isolated finds, radiocarbon dates which are often questionable, and sites researched quite a few decades ago. However, it should be emphasised that alternative concepts of Neolitization in the Northern Black Sea area have a probative base of the same and even weaker nature. In doing so, this concept is at a doubtless advantage, because it conforms remarkably to the general tendency of historical development of the region, which although remote, is an integral part of the Mediterranean. The existence of settlements of Mediterranean civilizations spread mainly by sea (ancient Greek colonies, Roman and Byzantine towns, the fortresses and trading stations of Genoa and the Republic of Venice) confirms it here. Therefore, I consider the current publication only as a first step in promising research into this newly discovered phenomenon in the archaeology of the Northern Black Sea area.

I am very grateful to Dr. Mykola Tovkaylo (Institute of Archaeology, Kyiv, UA), who kindly provided me with some unpublished results of his research, and to Dr. Valentin Prisyazhnyuk (Institute of Geology, Kyiv, UA) for the identification of ostracod and mollusc species from the raw material of the Neolithic pottery. Also, my deep gratitude goes to Professor Lech Czerniak (Institute of Archaeology, Gdansk University, PL), Professor Aleksander Kośko (Prehistory Institute, Adam Mickiewicz University, Poznań, PL), Dr. Nataliia Burdo, Dr. Sergiy Telizhenko, Dr. Mykhailo Videiko, Dr. Oleksandr Yanevich (all at the Institute of Archaeology, Kyiv, UA) for helpful discussions and encouragement of the conception of the North Pontic Impresso, and to Dr. Dmytro Kiosak (Odessa Archaeological Museum, UA) for his revision of the original English text and useful information. And lastly, many thanks are due also to Professor Mihael Budja (Ljubljana University) for his kind offer to publish the article in 'Documenta Praehistorica'. 


\section{REFERENCES}

ALGAN O., YALÇIN M. N., ÖZDOĞAN M., YILMAZ I., SARI E., KIRCI-ELMAS E., ONGAN D., BULKAN-YEŞILADALI Ö., YILMAZ Y. and KARAMUT I. 2009. A short note on the geoarcheological significance of the ancient Theodosius harbour (Istanbul, Turkey). Quaternary Research 72(3): 457-461.

ALIYEV T., HELWING B. 2009. Kamiltepe in der Milebene. Archaälogische Untersuchungen 2009. In H. Svend, M. Wagner, B. Helwing (eds.), Archäologische Mitteilungen aus Iran und Turan 41: 23-45.

AMIRKHANOV K. A. 1987. Chokhskoe poselenie. Chelovek $i$ ego kul'tura $v$ mezolite $i$ neolite gornogo Dagestana [The Choch settlement. A man and his culture in the Mesolithic and Neolithic of the mountain Dagestan]. Nauka, Moscow (in Russian).

ATHERSUCH J., HORNE D. J. and WHITTAKER J. E. 1989. Marine and brackish water ostracods (superfamilies Cypridacea and Cytheracea): keys and notes for the identification of the species. Synopses of the British fauna (New Series), 43. E. J. Brill, Leiden.

BADALYAN R., LOMBARD P., CHATAIGNER C. and AVETISYAN P. 2004. The Neolithic and Chalcolithic Phases in the Ararat Plain (Armenia): The View from Aratashen. In A. Sagona (ed.), A View from the Highlands: Archaeological Studies in Honour of Charles Burney. Ancient Near Eastern Studies, Supplement 12. Peeters, Leuven: 399420 .

BADALYAN R., LOMBARD P., AVETISYAN P., CHATAIGNER C., CHABOT J., VILA E., HOVSEPYAN R., WILLCOX G. and PESSIN H. 2007. New data on the late prehistory of the Southern Caucasus. The excavations at Aratashen (Armenia): preliminary report. In B. Lyonnet (ed.), Les Cultures du Caucase (VIe-IIIe millénaires avant notre ère). Leurs relations avec le Proche-Orient. CNRS Éditions (Éditions Recherche sur les Civilisations). Paris: 37-61.

BADALYAN R., HARUTYUNYAN A., CHATAIGNER C., LE MORT F., CHABOT J., BROCHIER J.-E., BALASESCU A., RADU V. and HOVSEPYAN R. 2010. The settlement of Aknashen-Khatunarkh, a Neolithic site in the Ararat plain (Armenia): excavation results 2004-2009. Turkiye Bilimler Akademisi arkeoloji dergisi (TÜBA-AR) 13: 185-218.

BELANOVSKAYA T. D. 1995. Iz drevneishego proshlogo Nizhnego Podon'ya [From the oldest past of the Lower Don Area]. Sankt-Petersburg university press, Sankt-Petersburg (in Russian).

BERCIU D. 1966. Cultura Hamangia. Editura Academiei Republicii Socialiste România, Bucureşti.
BIAGI P., KIOSAK D. 2010. The Mesolithic of the northwestern Pontic region. New AMS dates for the origin and spread of the blade and trapeze industries in southeastern Europe. Eurasia Antiqua. Zeitschrift für die Archäologie Eurasiens 16: 21-41.

BIAGI P., SHENNAN S. and SPATARO M. 2005. Rapid Rivers and Slow Seas? New Data for the Radiocarbon Chronology of the Balkan Peninsula. In L. Nikolova, J. Fritz, J. Higgins (eds.), Prehistoric Archaeology \& Anthropological Theory and Education. Reports of Prehistoric Research Projects 6-7: 41-52.

BIAGI P., SPATARO M. 2005. New Observations on the Radiocarbon Chronology of the Starčevo-Criş and Körös Cultures. In L. Nikolova, J. Fritz, J. Higgins (eds.), Prehistoric Archaeology \& Anthropological Theory and Education. Reports of Prehistoric Research Projects 6-7: 35-40.

BRANDAGLIA M. 2002. Isola del Giglio. In M. A. Fugazzola Delpino, A. Pessina, V. Tiné (eds.), Le ceramiche impresse nel Neolitico antico, Italia e Mediterraneo. (Bullettino di Paletnologia Italiana. Studi di Paletnologia I). Istituto Poligrafico e Zecca dello Stato, Roma: 407-423.

BRONK RAMSEY C. 1995. Radiocarbon calibration and analysis of stratigraphy: The 0xCal program. Radiocarbon 37(2): 425-430.

BRÜCKNER H., VÖTT A., SCHRIEVER A. and HANDL M. 2005. Holocene delta progradation in the eastern Mediterranean - case studies in their historical context. Méditerranée 104: 95-106.

CHAIRKINA N. M. 2009. Kul'turno-khronologicheskaya spetsifika neoliticheskikh kompleksov Severnogo Zaural'ya [The cultural-chronological characteristic of Neolithic complexes of the Northern Transural Area]. In S. A. Vasil'ev (ed.), Vzaimodejstvie i khronologiya kul'tur mezolita $i$ neolita Vostochnoy Evropy. Materialy Mezhdunarodnoy nauchnoy konferencii, posvyashchennoy 100-letiyu N. N. Gurinoy. IIMK RAN / MAE RAN, Sankt-Peterburg: 179-181 (in Russian).

CHEN F., YU Z., YANG M., ITO E., WANG S., MADSEN D. B., HUANG X., ZHAO Y., SATO T., BIRKS H. J. B., BOOMER I., CHEN J., AN C. and WÜNNEMANN B. 2008. Holocene moisture evolution in arid central Asia and its out-of-phase relationship with Asian monsoon history. Quaternary Science Reviews 27: 351-364.

CONNOR S., SAGONA A. 2007. Environment and society in the late prehistory of southern Georgia, Caucasus. In B. Lyonnet (ed.), Les Cultures du Caucase (VIe-IIIe millénaires avant notre ère). Leurs relations avec le Proche- 
Orient. CNRS Éditions (Éditions Recherche sur les Civilisations). Paris: 21-36.

DANILENKO V. N. 1969. Neolit Ukrainy: Glavy drevney istorii Yugo-Vostochnoy Evropy [The Neolithic of Ukraine: The chapters of ancient history of the South-eastern Europe]. Naukova dumka. Kiev (in Russian).

DAVISON K., DOLUKHANOV P., SARSON G. R. and SHUKUROV A. 2006. The role of waterways in the spread of the Neolithic. Journal of Archaeological Science 33: 641-652.

DINIZ M. 2007. O sítio da Valada do Mato (Évora): aspectos da neolitização no Interior/Sul de Portugal. Trabalhos de Arqueologia, 48. Instituto Português de Arqueologia. Lisboa.

DOLUKHANOV P. M., MAZURKEVICH A. M. and SHUKUROV A. M. 2009. Early pottery makers in Eastern Europe: centres of origins, subsistence and dispersal. In P. Jordan, M. Zvelebil (eds.), Ceramics before Farming: the Dispersal of Pottery among Prehistoric Eurasian Hunter-Gatherers. University College London, Institute of Archaeology Publications. Left Coast Press, Walnut Creek, Ca.: 237-253.

FLEMMING N. C. 2004. Submarine prehistoric archaeology of the Indian continental shelf: A potential resource. Current Science 86(9): 1225-1230.

FORENBAHER S., MIRACLE P. T. 2005. The spread of farming in the Eastern Adriatic. Antiquity 79: 514-528.

GALILI E., WEINSTEIN-EVRON M., HERSHKOVITZ I., GOPHER A., KISLEV M., LEMAU 0., KOISKA-HORWITZ L. and LEMAU H. 1993. Atlit-Yam: A Prehistoric Site on the Sea Floor off the Israeli Coast. Journal of Field Archaeology 20(2): 133-157.

GASKEVYCH D. 2001. Regional'ni osoblyvosti u neolitizacii Pripyats'kogo Polissya [Regional distinctions of neolithization in the Pripyat river basin]. Gistarychna-arhealagichny zbornik 16: 36-49 (in Ukrainian).

2006. Vita-Poshtova 2 - New The Easternmost Site of The Linear Band Pottery Culture. Sprawozdania Archeologiczne 58: 205-221.

2007. Sinkhronisatsia bugo-dnistrovs'kogo neolitu ta neolitu Tsentralnoy Evropy: Problema radiovugletsevykh dat [Synchronization of the Bug-Dniester Neolithic and Neolithic of Central Europe: Problem of radiocarbon dates]. In M. Gierlach (ed.), Wspólnota dziedzictwa archeologicznego ziem Ukrainy $i$ Polski. Materiały z konferencji zorganizowanej przez Ośrodek Ochrony Dziedzictwa Archeologicznego. (Łańcut, 2628.X.2005). Petit S.C., Lublin: 115-147 (in Ukrainian).
2009. Proiskhozhdenie keramiki s grebenchatoy ornamentatsiey v neolite Severnogo Prichernomor'ya [Origin of the Neolithic pottery with comb decoration in the Northern Black Sea Area]. In S. A. Vasil'ev (ed.), Vzaimodeistvie i khronologiya kul'tur mezolita $i$ neolita Vostochnoy Evropy. Materialy Mezhdunarodnoy nauchnoy konferencii, posvyashchennoy 100-letiyu N. N. Gurinoy. IIMK RAN/MAE RAN, Sankt-Peterburg: 146-148 (in Russian).

2010. Severo-pontiyskoe impresso: proiskhozhdenie neoliticheskoy keramiki s grebenchatym ornamentom na yuge Vostochnoy Evropy [North-Pontic Impresso: origin of the Neolithic pottery with comb decoration in the South of Eastern Europe]. STRATUM plus 2: 213251 (in Russian).

GUILAINE J., FREISES A. and MONTJARDIN R. avec la collaboration de BARBAZA M., COULAROU J., COURTIN J., DELIBRIAS G., DESSE J., DESSE G., GAY M.-C., GEDDÈS D., MASSON A., MONACO A., POPLIN F., POULAIN T., RICO-DE BOUARD M., THOMMERET J., THOMMERET Y., VERNET J.L. and VILETTE P. 1984. Leucate-Corrège, habitat noyé du Néolithique cardial. Centre d'Anthropologie des Sociétés Rurales, Toulouse et Musée Paul-Valéry, Sète.

GULIEV F., GUSEJNOV F. and ALMAMEDOV H. 2009. Excavations of a Neolithic Settlement at Goytepe (Azerbaijan). In B. Helwing, V. Ioseliani (eds.), Azerbaijan - Land between East and West. Transfer of knowledge and technology during the "First Globalization" of the VIIth-IVth millennium BC. (International Symposium Baku, April 1-3 2009). Deutsches Archäologisches Institut, EurasienAbteilung, Berlin: 29-30.

GURIN U. G. 1992. Doslidzhennya stoyanki Pidgorovka na Aydari [The research of the Pidgorovka site on the Aydar river]. Arkheologiya 2: 144-152 (in Ukrainian).

HANSEN S., MIRTSKHULAVA G. and BASTERT-LAMPRICHS K. 2009. Aruchlo: a Neolithic Settlement Mound in the Republic of Georgia. In B. Helwing, V. Ioseliani (eds.), Azerbaijan - Land between East and West. Transfer of knowledge and technology during the "First Globalization" of the VIIth-IVth millennium BC. (International Symposium Baku, April 1-3 2009). Deutsches Archäologisches Institut, Eurasien-Abteilung, Berlin: 19-22.

KADROW S. 2007. Kontakty kultur środkowoeuropejskich ze środowiskiem kulturowym na terenach Ukrainy we wczesnym neolicie - wybrane zagadnienia In M. Gierlach (ed.), Wspólnota dziedzictwa archeologicznego ziem Ukrainy $i$ Polski. Materiały z konferencji zorganizowanej przez Ośrodek Ochrony Dziedzictwa Archeologicznego. (Łańcut, 26-28.X.2005). Petit S.C., Lublin: 250-269.

KIGURADZE T., MENABDE M. 2004. The Neolithic of Georgia. In A. Sagona (ed.), A View from the Highlands: 
Archaeological Studies in Honour of Charles Burney. Ancient Near Eastern Studies, Supplement 12. Peeters, Leuven: 345-398.

KOTOVA N. S. 1994. Mariupol'skaya kul'turno-istoricheskaya oblast' (Dnepro-donskoe mezhdurech'e) [The Mariupol cultural-historic area (The Dnieper-Don interfluve)]. In Arkheologichni pam'yatky ta istoriya starodavn'ogo naselennya Ukrainy. Volume 1. Vezha, Kovel': 1-143 (in Russian).

1998. The role of eastern impulse in development of the Neolithic cultures of Ukraine. Baltic-Pontic Studies 5: $160-194$.

2002. Neolitizatsiya Ukrainy [Neolithization in Ukraine]. Shllyakh. Lugansk (in Russian).

2009. The neolithization of Northern Black Sea area in the context of climate changes. In M. Budja (ed.), 13th Neolithic Studies. Documenta Praehistorica 33: 159174.

KVAVADZE E., JALABADZE M. and SHAKULASHVILI N. 2010. Arguments indicating the presence of wine in Neolithic pots from Georgia using the method of palinological and chemical analysis. In Proceedings of the XXXIIIrd World Congress of Vine and Wine and the $8^{\text {th }}$ General Assembly of the International Organisation of Vine and Wine (20-25 June 2010, Tbilisi, Georgia). On-line: http:// www.oiv2010.ge/.

LARINA 0. 1994a. Neoliticul pe teritoriul Republicii Moldova. Thraco-Dacia XV(1-2): 41-66.

1994b. Culturi din epoca neolitică. Ştiinţa. Chişinau.

1999. Kul'tura lineyno-lentochnoy keramiki Pruto-Dnestrovskogo regiona [The Linear Pottery Culture of the area between rivers Prut and Dniester]. STRATUM plus 2: 10-140 (in Russian).

MANEN C. 2002. Structure et identité des styles céramiques du Néolithique ancien entre Rhône et Èbre. Gallia préhistoire 44: 121-165.

MAN'KO V. O. 2006. Neolit Pivdenno-skhidnoi Ukrainy [The Neolithic of the South-eastern Ukraine]. Kyiv (in Ukrainian).

NEPRINA V. I. 1969. Teterevskoe poselenie dnepro-donetskoy kul'tury [The Teteriv site of the Dnieper-Donets culture]. Sovetskaya arkheologiya 2: 134-139 (in Russian).

OPREANU P. 2003. Contribution to the Knowledge of Recent Ostracod Fauna from Some Danube Delta Lakes. GeoEco-Marina 9-10. On-line: http://www.geoecomar.ro/.
PERLES C. 2001. The early Neolithic in Greece. The first farming communities in Europe. Cambridge World Archaeology. Cambridge University Press. Cambridge.

PERRIN T., MARCHAND G., ALLARD P., BINDER D. avec la collaboration de COLLINA C., GARCIA PUCHOL 0. and VALDEYRON N. 2010. Le second Mésolithique d'Europe occidentale: origines et gradient chronologique (The late Mesolithic of Western Europe: origins and chronological stages). Annales de la Fondation Fyssen 24: 160-176.

REIMER P. J., BAILLIE M. G. L., BARD E., BAYLISS A., BECK J. W., BERTRAND C., BLACKWELL P. G., BUCK C. E., BURR G., CUTLER K. B., DAMON P. E., EDWARDS R. L., FAIRBANKS R. G., FRIEDRICH M., GUILDERSON T. P., HUGHEN K. A., KROMER B., McCORMAC F. G., MANNING S., BRONK RAMSEY C., REIMER R. W., REMMELE S., SOUTHON J. R., STUIVER M., TALAMO S., TAYLOR F. W., VAN DER PLICHT J. and WEYHENMEYER C. E. 2004. IntCal04 Terrestrial Radiocarbon Age Calibration, 0-26 cal kyr BP. Radiocarbon 46(1): 1029-1058.

ROSTUNOV V. L., LJACHOV S. and REINHOLD S. 2009. Cmi - Eine Freilandfundstelle des Spätmesolithikums und Frühneolithikums in Nordossetien (Nordkaukasus). In H. Svend, M. Wagner, B. Helwing (eds.), Archäologische Mitteilungen aus Iran und Turan 41: 47-74.

SHIRAI N. 2010. The Archaeology of the First FarmerHerders in Egypt. New Insights into the Fayum Epipalaeolithic and Neolithic. Leiden University Press. Leiden.

SHORIN A. F. 2009. Khronostratigrafiya neoliticheskikh kompleksov Koksharovskogo kholma v Srednem Zaural'e [The chronology and stratigraphy of the Koksharovsky Kholm Neolithic complexes in the Middle Transural region]. In S. A. Vasil'ev (ed.), Vzaimodejstvie i khronologiya kul'tur mezolita i neolita Vostochnoy Evropy. Materialy Mezhdunarodnoy nauchnoy konferencii, posvyashchennoy 100-letiyu N. N. Gurinoy. IIMK RAN / MAE RAN, Sankt-Peterburg: 176-178 (in Russian).

SOLECKI R. L., SOLECKI R. S. 1970. Grooved Stones from Zawi Chemi Shanidar, a Protoneolithic Site in Northern Iraq. American Anthropologist 72(4): 831-841.

STANKO V. N. 1966. Mezoliticheskaya stoyanka Ghirzhevo v Odesskoy oblasti (1962-1964 gg.) [The Ghirzhove Mesolithic site in the Odessa area (1962-1964)]. Sovetskaya arkheologiya 2: 96-103 (in Russian).

1967. Nekotorye voprosy pozdnego mezolita SeveroZapadnogo Prichernomor'ya (po materialam raskopok stoyanki Ghirzhevo) [Some problems of the Late Mesolithic of the Northwestern Black Sea area]. Zapiski Odesskogo arkheologicheskogo obshchestva 2(35): 155-168 (in Russian). 
TELEGIN D. Y. and TITOVA E. N. 1998. Poseleniya dnepro-donetskoy etnokul'turnoy obshchnosti epokhi neolita: Svod arkheologicheskikh istochnikov [The settlements of the Dnieper-Donets ethno-cultural community of the Neolithic age: Corpus of archaeological sources]. Naukova dumka. Kiev (in Russian).

TELEGIN D. J., KOVALIUKH N. N., POTEKHINA I. D. and LILLIE M. 2000. Chronology of Mariupol type cemeteries and subdivision of the Neolithic-Copper Age Cultures into periods for Ukraina. Radiocarbon and Archaeology 1: 59-74.

TOVKAYLO M. 2005. Neolit stepovogo Pobuzhzhya [The Neolithic of the steppe part of the Southern Buh river basin]. Shlyakh, Kyiv (in Ukrainian).

2010. Rann'oneolitychniy goryzont poselennya Gard i problema neolityzatsii Pivnichnozakhidnogo Nadchornomor'ya ta Pobuzhzhya [The Early Neolithic horizon of the Gard settlement and a problem of the neolithization in the Northwest Black Sea Area and the Southern Buh basin]. Kam'yana doba Ukrainy 13: 208-228 (in Ukrainian).

TUBOLTSEV 0. V. 2005. Neopublikovannye materialy po rannemu neolitu Nadporozh'ya [Not published formerly materials about Early Neolithic of the Dnipro river rapids region]. Starozhitnosti stepovogo Prychornomor'ya $i$ Krymu XII: 28-49 (in Russian).

USACHEVA I. V. 2005. 'Utyuzhki' v kul'turakh Evrazii ['Utyuzhki' in cultures of Eurasia]. Vestnik arkheologii, antropologii i etnografii 6: 12-23 (in Russian).

VIDEYKO M. Y., KOVALYUKH M. M. 1998. Izotopne datuvannya pam'yatok bugo-dnistrovs'koi kul'tury [Radioisotopic dating of the Buh-Dniester culture sites]. In D. N. Kozak, N. 0. Gavrylyuk (eds.), Arkheologichni vidkryttya $v$ Ukraini 1997-1998 rr. Institute of Archaeology NASU. Kyiv: 65-66 (in Ukrainian).

WECHLER K.P. 1997a. Transverse Grooved Stones and the Neolithization of Eastern Europe. Neo-Lithics 1: 18-19. 1997b. Poliroval'niki und das Neolithikum der Steppe und Waldsteppe Osteuropas. In C. Becker et al. (eds.), Chronos. Contributions to prehistoric archaeology from North to Southeast Europe. Studies in honour of Bernhard Hänsel. Verlag Marie Leidorf GmbH. Espelkamp: 107-123.

ZALIZNYAK L. 1998a. Peredistoriya Ukrainy X-V tys. do n.e. [Prehistory of Ukraine $X-V$ millenium BC]. Biblioteka ukraintsya. Kyiv (in Ukrainian).

1998b. The Late Mesolithic subbase of the Ukrainian Neolithic. Baltic-Pontic Studies 5: 120-145.

2005. Final'nyi paleolit $i$ mezolit kontynental'no $i$ Ukrainy. Kul'turnyi podil ta periodyzatsiya [The Final Palaeolithic and Mesolithic of mainland Ukraine: Cultural division and periodization]. Shlyakh. Kyiv (in Ukrainian).

ZALIZNYAK L. L., BALAKIN S. A. and OKHRIMENKO G. V. 1987. Neolitychni poselennya Korma-1 ta Krushnyky na Zhitomyrshchyni [The Neolithic sites Korma-1 and Krushnyky in the Zhitomyr area]. Arkheologiva 58: 64-73 (in Ukrainian).

ZALIZNYAK L. L., MAN'KO V. 0. 2004. Stoyanky bilya s. Dobryanka na r. Tikych ta deyaki problemy neolityzatsii Seredn'ogo Podniprov'ya [The sites near Dobryanka village on the Tikych river and some problems of neolithization in the Middle Dnieper Area]. Kam'yana doba Ukrainy 5: 137-168 (in Ukrainian).

ZILHÃO J. 2001. Radiocarbon evidence for maritime pioneer colonization at the origins of farming in west Mediterranean Europe. Proceedings of the National Academy of Sciences of the United States of America 98(24): 14180-14185.

ZVELEBIL M., LILLIE M. 2000. Transition to agriculture in Eastern Europe. In T. D. Price (ed.), Europe's First Farmers. Cambridge University Press. Cambridge: 57-92. 